\title{
MODEL PEMILIHAN SERVER SIDE SCRIPTING UNTUK SISTEM INFORMASI SEKOLAH: STUDI KOMPARASI ASP, JSP, PHP, PYTHON, DAN RUBY
}

\author{
Dewi Mustari \\ Fakultas Teknik Matematika dan IPA, Program Studi Teknik Informatika, Universitas Indraprasta PGRI \\ Jl Nangka No 58E Tanjung Barat, Jakarta Selatan, Indonesia \\ E-mail: mustaridewi@yahoo.com
}

\begin{abstract}
Abstrack
There are many criteria that could be used as the basis for the selection of server side scripting that could be applied to the school information system. This study compares several server side scripting that could be applied the school information system. Those server side scripting are ASP, JSP, PHP, Python, and Ruby. This research refers to research done by Oyku Alanbay regarding the selection of softwares. In addition, using the theories regarding the quality of the software as the basis for the determination of selection sub criteria server side scripting to the school information system. In the selection of server side scripting for this school information system with three levels of criteria. As for the level 1 criteria is technology related, user related, and vendor related, level 2 criterion consists of $18 \mathrm{sub}$ criteria obtained from the special advantages for server side scripting. And level 3 there are five alternatives is ASP, JSP, PHP, Python, and Ruby. In the selection of server side scripting for this school information systems using Analytical Hierarchy Process (AHP) and the tool uses Expert Choice 2000. The results of this election make PHP as server side scripting needs compared to ASP, JSP, Python, and Ruby with $40.6 \%$ weighting values with the most influential factor was $60.4 \%$ of the user related.
\end{abstract}

Keywords: Server Side Scripting, Theory Oyku Alanbay, Analytical Hierarchy Process, Expert Choice 2000.

\begin{abstract}
Abstrak
Dalam menentukan server side scripting, banyak kriteria yang dapat digunakan sebagai dasar pemilihan server side scripting yang sesuai dengan kebutuhan untuk diterapkan pada sistem informasi sekolah. Penelitian ini mengangkat beberapa server side scripting untuk sistem informasi sekolah yaitu ASP, JSP, PHP, Python, dan Ruby. Penelitian ini mengacu pada penelitian Oyku Alanbay yang membahas mengenai pemilihan perangkat lunak. Selain itu, peneltian ini juga menggunakan teori mengenai kualitas perangkat lunak sebagai dasar penetapan sub kriteria pemilihan server side scripting untuk sistem informasi sekolah.

Pemilihan server side scripting untuk sistem informasi sekolah ini digunakan tiga level kriteria. Adapun level 1 kriteria yaitu technology related, user related, dan vendor related, level 2 kriteria terdiri dari 18 sub kriteria yang didapat dari kelebihan khusus untuk server side scripting. Dan level 3 alternatif ada lima yaitu ASP, JSP, PHP, Python, dan Ruby. Dalam pemilihan server side scripting untuk sistem informasi sekolah ini menggunakan Analytical Hierarchy Process (AHP) dengan tool menggunakan Expert Choice 2000. Hasil pemilihan ini menghasilkan PHP sebagai server side scripting yang sesuai dengan kebutuhan dibandingkan ASP, JSP, Python, dan Ruby dengan nilai bobot $40,6 \%$ dengan faktor yang paling berpengaruh adalah user related $60,4 \%$.
\end{abstract}

Kata Kunci: Server Side Scripting, Teori Oyku Alanbay, Analytical Hierarchy Process, Expert Choice 2000

\section{Pendahuluan}

Dengan berkembangnya teknologi informasi yang cepat akan membawa perubahan yang signifikan terhadap berbagai bidang tidak terkecuali dibidang pendidikan. Teknologi informasi memungkinkan terjadinya proses komunikasi yang bersifat global diseluruh penjuru dunia. Dengan adanya teknologi informasi memberikan pilihan di dunia pendidikan untuk turut serta dalam pemanfaatannya baik itu untuk sistem pembelajaran maupun dalam pelayanan serta administrasi yang berbasis teknologi informasi. Saat ini Sekolah Menengah Kejuruan Yapimda belum memiliki website sendiri, namun selama ini dapat mengakses informasi mengenai sekolah bisa dilihat di website yayasan yaitu www.yapimda.org. Namun informasi yang ada 
belum bisa memenuhi harapan penggunanya dan informasinya pun hanya menampilkan gambar dan profil saja.

Oleh sebab itu, pihak sekolah merasa perlu untuk mengembangkan sistem informasi sekolah menengah kejuruan Yapimda yang berbasis web untuk mengatasi kekurangan yang ada dari sistem informasi tersebut. Pihak sekolah masih ragu dalam menentukan server-side scripting yang mana yang akan digunakan untuk sistem informasi sekolah nanti. Oleh sebab itu, ada lima server-side scripting yang diusulkan kepada pihak sekolah dengan memberikan penjelasan mengenai kelebihan dan kekurangan dari setiap server-side scripting. Metode yang digunakan dalam pengambilan keputusan yaitu Analytic Hierarchy Process (AHP). Berdasarkan hasil survey peneliti, Server side scripting yang popular dan sering digunakan oleh programmer ada 5 Server Side Scripting, sehingga peneliti mengambil kesimpulan untuk menggunakan 5 server side scripting tersebut dalam penelitian ini. Server side scripting yang menjadi objek penelitian adalah ASP, JSP, PHP, Python, dan Ruby sehingga pihak sekolah dapat mempertimbangkan server-side scripting mana yang akan dipilih. Dari hasil pemilihan tersebut akan menghasilkan keputusan server side scripting yang akan digunakan untuk sistem informasi sekolah.

Tujuan yang ingin dicapai dalam penelitian ini yaitu untuk mengetahui kriteria yang menjadi penilaian dalam pemilihan server side scripting dan untuk mengetahui sub-sub kriteria berdasarkan teknologi, user, dan vendor dalam pemilihan server side scripting. Serta untuk mengetahui server side scripting yang dipilih untuk diterapkan pada sistem informasi di Sekolah Menengah Kejuruan Yapimda.

Pengambilan keputusan merupakan pemilihan diantara beberapa alternatif pemecahan masalah. Pada hakikatnya keputusan diambil jika pimpinan menghadapi masalah atau untuk mencegah timbulnya masalah dalam organisasi yang bergerak baik dalam bidang sosial maupun komersial. Ada dua kemungkinan sifat tujuan dari pengambilan keputusan. Pertama adalah tujuan pengambilan keputusan yang bersifat tunggal dalam arti bahwa sekali diputuskan tidak akan ada kaitannya dengan masalah lain. Kemungkinan kedua adalah tujuan pengambilan keputusan dapat bersifat ganda dalam arti bahwa satu keputusan yang diambil sekaligus memecahkan dua masalah atau lebih.

Untuk itu maka model pengambilan keputusan sangatlah penting untuk membantu para pengambil keputusan dan mengambil keputusan. Ada beberapa macam model keputusan antara lain model simulasi komputer, model pohon keputusan, model probabilistik dan lain sebagainya. Model adalah percontohan yang mengandung unsur yang bersifat penyederhanaan untuk dapat ditiru (jika perlu). Pengambilan keputusan itu sendiri merupakan suatu proses berurutan yang memerlukan penggunaan model secara cepat dan benar.

Server-side scripting adalah scripting yang dieksekusi melalui web server seperti Apache. Server-side scripting sangat berguna ketika dibutuhkan suatu fungsi ataupun validasi yang terhubung dengan basis data, keamanan server ataupun proses melalui server [1]. Pengguna server-side scripting biasanya merupakan indikasi bahwa aplikasi web tersebut bersifat dinamis. Cara kerja server-side scripting dapat diibaratkan sebagai satu set instruksi yang diproses oleh server, dan menghasilkan HTML. HTML yang dihasilkan dikirim sebagai bagian dari tanggapan HTTP ke browser. Browser kemudian menampilkan HTML tersbut.

Sistem Informasi adalah suatu sistem di dalam suatu organisasi yang mempertemukan kebutuhan pengolahan transaksi harian, mendukung operasi, bersufat manajerial dan kegiatan strategi dari suatu organisasi dan menyediakan pihak luar tertentu dengan laporanlaporan yang diperlukan [2].

Mengambil keputusan adalah suatu proses yang dilaksanakan orang berdasarkan pengetahuan dan informasi yang ada dengan harapan bahwa akan terjadi. Keputusan dapat diambil dari alternatif-alternatif keputusan yang ada. Alternatif keputusan itu dapat dilakukan dengan adanya informasi yang diolah dan disajikan dengan dukungan sistem penunjang keputusan. Adapun informasi terbentuk dari adanya data yang terdiri dari bilangan dan terms yang disusun, diolah, dan disajikan dengan dukungan sistem informasi manajemen. Kemudian keputusan yang diambil ditindaklanjuti dengan aksi yang dalam pelaksanaannya perlu mengacu pada standar prosedur operasi, dan akan membentuk kembali data, begitu seterusnya yang terjadi pada siklus data, informasi, keputusan, dan aksi.

Pengambilan keputusan dapat dilakukan dengan dua kerangka kerja, yaitu: Pengambilan keputusan tanpa percobaan dan pengambilan keputusan yang berdasarkan suatu percobaan [3]. Pengambilan keputusan tanpa berdasarkan eksperimen, dilakukan dengan cara menyusun secara sistematis cara kerja umum sebelum mencari solusi bagi masalah yang diharapkan. Teori ini dikembangkan sejalan dengan pendekatan statistik di mana secara sederhana, keputusan yang dihasilkan diupayakan mempunyai pengaruh kesalahan seminimum 
mungkin.

Model AHP dikembangkan oleh Thomas L. Saaty seorang ahli matematika yang telah memberikan kontribusi dalam bidang operatio research dan telah menulis lebih dari 35 buku serta makalah tenatang AHP. Software yang dapat digunakan untuk memecahkan masalah AHP adalah Expert Choice merupakan perangkat lunak yang dapat digunakan untuk perhitungan pemecahan persoalan dengan AHP [4]. Pada penulisan penelitian ini, digunakan analisis ganda dengan perhitungan sesuai formula dan juga perhitungan dengan menggunakan tools Expert Choice 2000. Tujuan dilakukan analisis ganda ini adalah untuk membandingkan dan membuktikan analisa perhitungan yang dilakukan sesuai dengan aplikasi Expert Choice yang sudah teruji kehandalannya. Expert Choice mampu membuat perhitungan sampai tujuh level yang terdiri dari ribuan kriteria atau alternatif. Selain itu Expert Choice dapat menunjukkan bagian mana yang tidak konsisten, sehingga jika inkonsistensi sudah di luar toleransi, kita tinggal menghubungi kembali responden bersangkutan untuk memperbaiki bagian dari pilihannya yang tidak konsisten.

Peneliti merujuk dari penelitian sebelumnya dengan case yang berbeda yaitu:

1) Penelitian Oyku Alanbay [5], yang menjelaskan mengenai ERP selection using Expert Choice software, tentunya dengan karakteristik yang berbeda dan objek yang berbeda juga. Untuk penelitian yang membahas mengenai server side scripting belum ada yang meneliti sehingga peneliti tergerak untuk meneliti objek tersebut, yang tentunya akan berguna bagi sekolah yg ingin mengembangkan atau membuat aplikasi sistem informasi berbasis web dengan mempertimbangkan hal-hal yang menjadi pertimbangan dalam pemilihan server side scripting yang berhubungan dengan bahasa pemrograman yang akan digunakan untuk membuat web sekolah. Dilihat dari sub-sub kriteria yang diuraikan oleh peneliti.

2) Penelitian Hilyah Magdalena [6], yang menjelaskan mengenai pemilihan software berbasis open source untuk aplikasi digital library berbasis web. Penelitian ini menggunakan metode yang sama yaitu AHP, dengan objek penelitian yang berbeda sehingga tentunya ada perbedaan sub kriteria dari penelitian ini.

\section{Metode Penelitian}

Berdasarkan jenis informasi yang dikelola, jenis penelitian ini adalah penelitian deskriptif kuantitatif. Penelitian deskriptif merupakan penelitian yang dilakukan untuk mengetahui nilai variabel mandiri (independen) tanpa membuat perbandingan atau membangun hubungan dengan variabel yang lain [7]. Penelitian kuantitatif yaitu suatu metode penelitian yang terorganisir dengan menekankan data kuantitatif sebagai titik tolak kajian. Karena dalam penelitian ini melibatkan data, perhitungan (komputasi) dan penarikan kesimpulan. Oleh sebab itu, dilakukan pengujian dari hipotesa dengan teknik-teknik statistika.

Dalam pemilihan sampel, pengambilan data dari populasi yang terbatas (limit population) dengan menggunakan purposive sampling, yaitu pengambilan sampel dilakukan atas dasar pertimbangan tertentu [2]. Responden yang diambil dalam pemilihan sampel ini adalah responden ahli yang berasal dari sekolah menengah kejuruan dan juga responden ahli eksternal. Para responden ahli yaitu mereka yang mengerti, memahami dan pernah menggunakan server side scripting dalam berbagai sistem informasi atau pun aplikasi berbasis web.

TABEL I

DAFTAR RESPONDEN AHLI

\begin{tabular}{|c|c|c|c|}
\hline No. & \multicolumn{2}{|c|}{ Responden } & Jumlah \\
\hline 1 & \multicolumn{2}{|c|}{$\begin{array}{l}\text { Kepala Sekolah Menengah Kejuruan } \\
\text { Yapimda. }\end{array}$} & 1 orang \\
\hline 2 & \multirow{2}{*}{\multicolumn{2}{|c|}{$\begin{array}{llr}\text { Staff Ahli } & \text { yaitu Guru } & \text { Multimedia } \\
\text { Sekolah } & \text { Menengah } & \text { Kejuruan } \\
\text { Yapimda } & & \\
\text { Manager IT } & \end{array}$}} & 2 orang \\
\hline 3 & & & 1 orang \\
\hline 4 & \multirow{2}{*}{\multicolumn{2}{|c|}{$\begin{array}{l}\begin{array}{l}\text { Dosen IT sebagai } \\
\text { (Programer) }\end{array} \\
\text { Developer (Programer) }\end{array}$}} & 1 orang \\
\hline 5 & & & 1 orang \\
\hline & \multicolumn{2}{|l|}{ Jumlah } & 6 orang \\
\hline
\end{tabular}

Dalam penelitian ini, peneliti mengambil 6 responden untuk mendapatkan data. 6 responden cukup mewakili dari setiap kiriteria yang di tentukan, sehingga data yang diperoleh dapat memenuhi kebutuhan data yang akan diolah. Responden no. 1 yaitu kepala sekolah merupakan responden yang bertanggungjawab dalam pengambilan keputusan, responden no. 2 merupakan guru dari sekolah yapimda yang merupan user sekaligus admin yang akan menggunakan aplikasi web pada saat implemntasi program, Responden no. 3 yaitu manajer IT merupakan responden ahli yang memahami, mengerti dan pernah mengimplementasikan serta memahami perkembangan aplikasi berbasis web pada dunia nyata yang merupakan vendor, responden no. 4 yaitu programmer merupakan responden yang biasa menggunakan server side scripting dalam pembuatan aplikasi berbasis web yang berasal dari vendor yaitu penyedia layanan pembuatan aplikasi web. 
Untuk mengumpulkan data dan informasi tersebut, dilakukan dengan 2 metode pengumpulan data yaitu:

a. Pengumpulan data primer dilakukan dengan cara mengumpulkan data dari responden ahli yang dikumpulkan dengan cara mengisi kuesioner.

b. Pengumpulan data sekunder dengan mengamati data, membaca, mempelajari dan mengutip dari buku literatur, jurnal, karya ilmiah, internet, serta sumber-sumber yang berhubungan erat dengan penelitian ini.

Instrumentasi utama yang digunakan dalam penelitian ini adalah kuesioner. Angket (questionnaire) adalah daftar pertanyaan yang diberikan kepada orang lain yang bersedia memberikan respon sesuai dengan dasar kegunaan. Kuesioner disusun dalam bentuk pertanyaan dengan mengacu kepada hirarki yang telah dibuat dari kriteria-kriteria dan sub-sub kriteria berdasarkan skala Saaty 1-9 dengan metode Pairwise Comparison. Penyusunan dan pengelompokan kriteria utama ini berdasarkan hirarki yang disusun oleh Oyku Alanbay [5] yaitu berdasarkan teknologi, user, dan vendor. Penyusunan komponen sub kriteria dari teori Oyku Alanbay [5] dan McCall [3] mengenai kualitas perangkat lunak. Penyusunan komponen alternatif sesuai dengan yang diajukan oleh pihak sekolah menengah kejuruan. Komponen alternatif yang diajukan oleh pihak sekolah yang merupakan server side scripting yang menjadi objek penelitian yaitu ASP, JSP, PHP, Python, dan Ruby.

Berikut ini hirarki Analytical Hierarchi Process (AHP) dalam pemilihan server side scripting untuk sistem informasi sekolah.

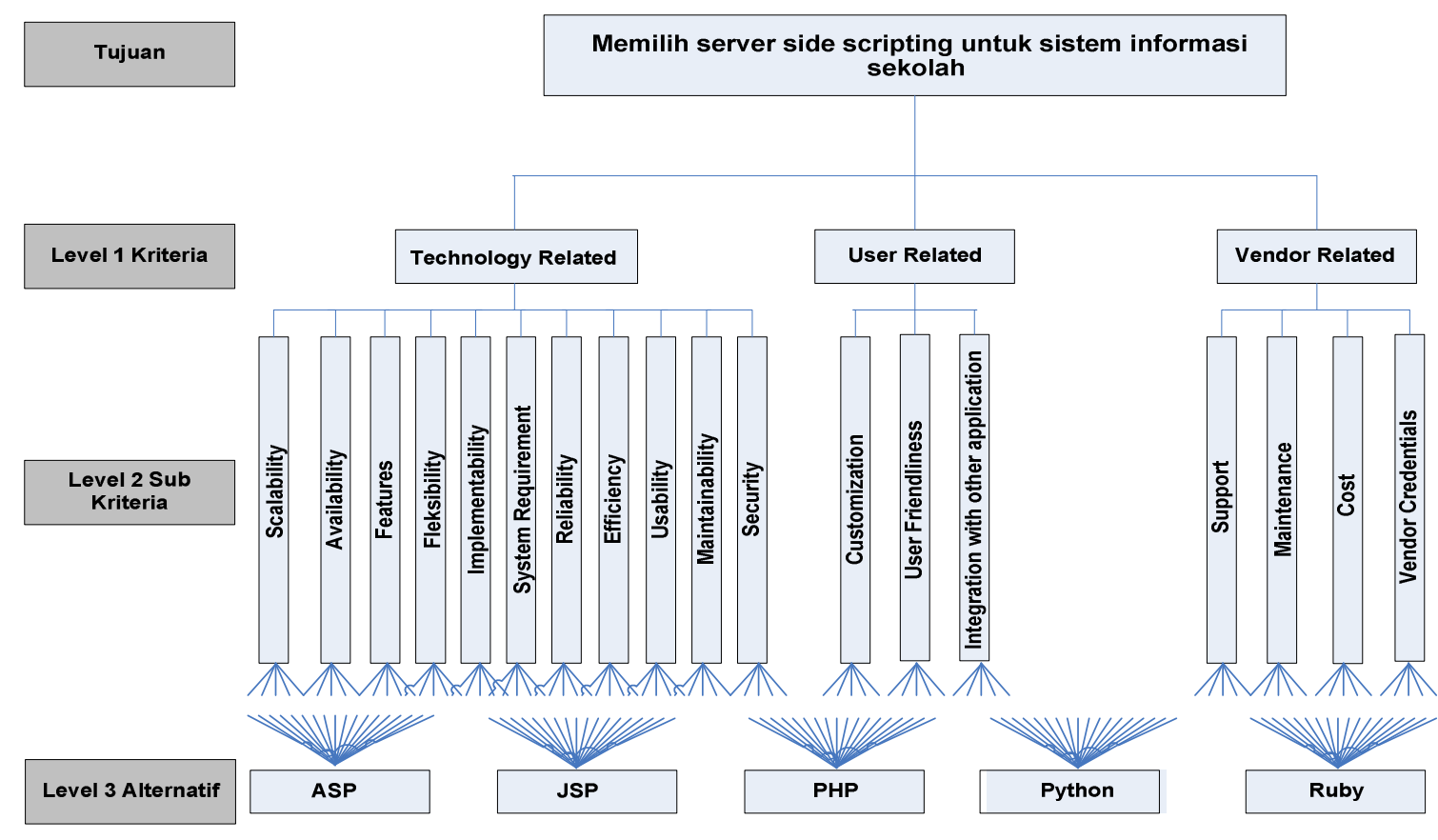

Gambar 1. Hirarki pemilihan server side scripting untuk sistem informasi sekolah

Berdasarkan Gambar 1, terdapat tiga kriteria di level 1 dan 18 sub kriteria di level 2 yang menjadi pertimbangan dalam pemilihan server side scripting untuk sistem informasi sekolah, yang masing-masing sub kriteria memiliki 5 (lima) pilihan alternatif yang berada di level 3 . Instrumentasi ini di sajikan pada lampiran 1 . Metode analsis data berdasarkan hasil kuesioner tentang strategi pemilihan server side scripting untuk sistem informasi sekolah memakai pendekatan proses hirarki dengan menggunakan aplikasi Analytical Hierarchy Process (AHP) yaitu Expert Choice 2000.

Teknik analisis data dimaksud dibagi menjadi enam langkah utama, yaitu:

1) Menyusun Diagram Hirarki AHP

2) Memasukkan data Matriks Pairwise Comparison per level per responden pada aplikasi Expert Choice.

TABEL II

CONTOH MATRIKS PAIRWISE COMPARISON

\begin{tabular}{cccc}
\hline & $\mathrm{A}_{1}$ & $\mathrm{~A}_{2}$ & $\mathrm{~A}_{3}$ \\
\hline $\mathrm{A}_{1}$ & 1 & $\mathrm{a}$ & $\mathrm{b}$ \\
$\mathrm{A}_{2}$ & $1 / \mathrm{a}$ & 1 & $\mathrm{c}$ \\
$\mathrm{A}_{3}$ & $1 / \mathrm{b}$ & $1 / \mathrm{c}$ & 1 \\
\hline
\end{tabular}


3) Memasukkan data Matrik Pairwise Comparison sesuai sub-kriteria per alternatif per responden

TABEL III

CONTOH MATRIKS PAIRWISE COMPARISON SUB KRITERIA DAN

\begin{tabular}{cccc}
\multicolumn{4}{c}{ ALTERNATIF } \\
\hline A1 & Alternatif 1 & Alternatif 2 & Alternatif 3 \\
\hline Alternatif 1 & 1 & $\mathrm{a}$ & $\mathrm{b}$ \\
Alternatif 2 & $1 / \mathrm{a}$ & 1 & $\mathrm{c}$ \\
Alternatif 3 & $1 / \mathrm{b}$ & $1 / \mathrm{c}$ & 1 \\
\hline
\end{tabular}

4) Lakukan perhitungan dengan dalam Expert Choice untuk menghitung hasil akhir seluruh responden yang pada intinya penggabungan pendapat responden mengikuti rumus [7].

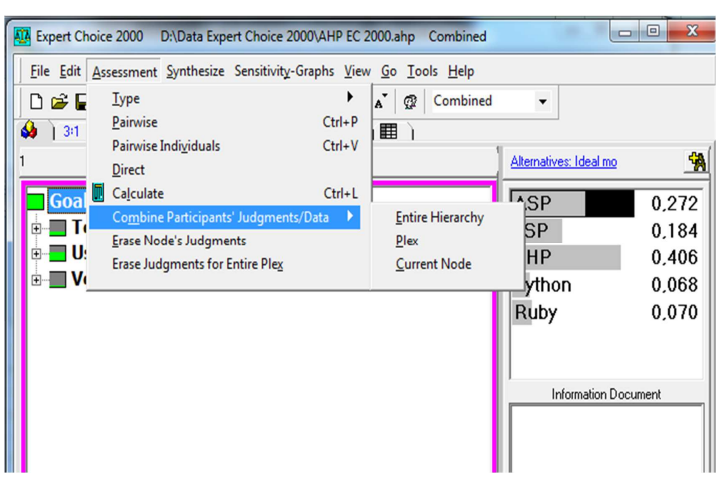

Gambar 2. Menu Perhitungan dalam Expert Choice

5) Cek Nilai Inconsistency Gabungan melalui Expert Choice dan hitung dengan Random Index Oarkridge Laboratory.

6) Kalkulasikan nilai yang diterima adalah Consistency ratio dengan nilai lebih kecil dan atau sama dengan 0,1 .

Pengukuran ini dimaksudkan untuk mengetahui konsistensi jawaban yang akan berpengaruh pada kesahihan hasil. Rumusnya adalah sebagai berikut:

$$
C I=\frac{\lambda_{\max }-n}{n-1}
$$

Dimana:

$$
\begin{array}{ll}
\mathrm{CI} & =\text { Consistensi Index } \\
\lambda_{\max } & =\text { Eigen Value } \\
\mathrm{n} & =\text { Jumlah yang dibandingkan }
\end{array}
$$

Untuk mengetahui apakah CI dengan besaran tertentu cukup baik atau tidak, perlu diketahui rasio yang dianggap baik, yaitu $\mathrm{CR} \leq$ 0,1. Rumus CR (Consistency ratio) adalah:

$$
C R=\frac{C I}{R I}
$$

Keterangan:

$$
\begin{array}{ll}
\text { CI } & =\text { Consistensi Index } \\
\mathrm{RI} & =\text { Random Index } \\
\mathrm{CR} & =\text { Consistency ratio }
\end{array}
$$

AHP dapat digunakan untuk mengolah data dari satu responden saja. Untuk responden yang lebih dari satu, maka untuk mendapatkan hasil perhitungannya, harus digabungkan menggunakan rata-rata geometrik dengan rumus sebagai berikut Marimin [3]:

$$
\overline{x_{G}}=\sqrt[n]{\pi_{i=1}^{n}} \cdot X_{i}
$$

Dimana:

$\overline{x_{G}} \quad=$ rata-rata geometrik

$\mathrm{n} \quad=$ jumlah responden

$\mathrm{X}_{\mathrm{i}} \quad=$ penilaian oleh responden ke-i

Hasil penilaian gabungan ini yang kemudian diolah dengan menggunakan software untuk $A H P$ yang dikenal dengan nama Expert Choice.

\section{Eksperimen dan Pembahasan}

Responden dalam pemilihan server side scripting untuk sistem informasi sekolah kejuruan ini seluruhnya berjumlah 6 (enam) orang responden yang merupakan responden ahli. Responden ahli merupakan respon yang memahami mengenai objek yang diteliti, serta pernah mengimplementasikannya dalam pekerjaannya. Server side scripting yang akan digunakan untuk sistem informasi sekolah kejuruan yang digunakan sebagai alternatif pilihan dalam penelitian ini. Server side scripting yang banyak digunakan dan populer dikalangan developer web yaitu ASP, JSP, PHP, Python, dan Ruby.

Proses selanjutnya yaitu membuat perbandingan berpasangan untuk level 3 yaitu alternatif. Setiap alternatif yang ada akan dilakukan perbandingan untuk masing-masing kriteria. Data untuk proses ini diambil melalui kuesioner yang diberikan kepada 6 (enam) responden, setelah itu data tersebut diolah dengan menggunakan Expert Choice 2000 untuk mendapatkan nilai rata-rata dari setiap perbandingan.

Hasil perhitungan dengan geometric mean tiap responden, akhirnya akan digabungkan, dan nilai hasil penggabungan tersebut akan dihitung tingkat consistency ratio-nya (CR) menggunakan tool Expert Choice 2000. Berikut adalah hasil yang didapat: 


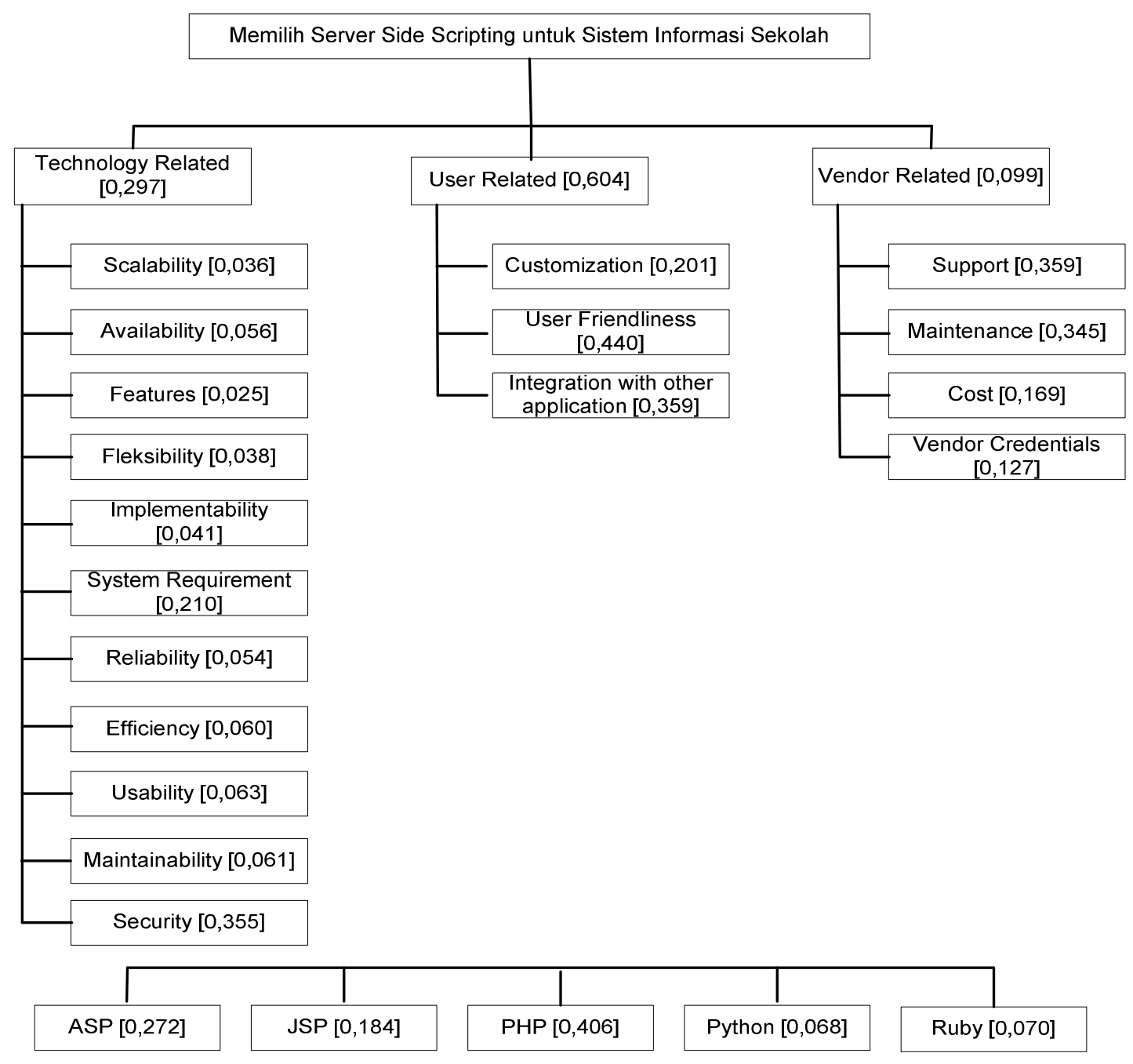

Gambar 3. Hirarki Pemilihan server side scripting untuk sistem informasi sekolah - Solusi yang dihasilkan

Dari hasil yang tertera dari Gambar 3 telah terlihat bahwa server side scripting yang dipilih adalah PHP dengan bobot 0,406, level berikutnya adalah ASP dengan bobot 0,272 , JSP dengan bobot 0,184 , Ruby dengan bobot 0,070 , dan yang terakhir Python dengan bobot 0,068 .

Berdasarkan hasil pengolahaan data responden ahli diperoleh bahwa prioritas utama atau tertinggi alternatif penentuan server side scripting adalah PHP dengan nilai bobot 0,406 atau sebanding dengan $40,6 \%$ dari total alternatif yang ditetapkan. Hasil bobot alternatif ini ternya sesuai dengan hipotesa yang dibuat pada perumusan masalah di bab sebelumnya. Kemudian peringkat prioritas alternatif berikutnya adalah ASP (nilai bobot 0,272 atau sebanding dengan 27,2\%), JSP (nilai bobot 0,184 atau sebanding dengan 18,4\%), Ruby (nilai bobot
0,070 atau sebanding dengan 7,0\%), dan Python (nilai bobot 0,068 atau sebanding dengan 6,8\%).

Persepsi strategis ini memberikan implikasi bahwa pemilihan server side scripting untuk sistem informasi sekolah kejuruan sesuai dengan mayoritas jawaban para responden berdasarkan kriteria, sub kriteria, dan alternatif yang dipilih oleh para responden.

Inconsistency ratio atau rasio inkonsistensi data responden merupakan parameter yang digunakan untuk memeriksa apakah perbandingan berpasangan telah dilakukan dengan konsekuen atau tidak. Rasio inkonsistensi data dianggap baik jika nilai $\mathrm{CR}$-nya $\leq 0.1$. Untuk mengecek rasio inkonsistensi data responden, berikut ini ditampilkan nilai rasio inkonsistensi pada masingmasing matriks perbandingan. 
TABEL IV

PERBANDINGAN ELEMEN DAN NILAI CR

\begin{tabular}{clcc}
\hline No & Matriks perbandingan elemen & $\begin{array}{c}\text { Nilai } \\
\text { CR }\end{array}$ \\
\hline 1 & $\begin{array}{l}\text { Perbandingan elemen kriteria level I berdasarkan sasaran pemilihan server side scripting untuk sistem informasi } \\
\text { sekolah kejuruan }\end{array}$ & 0,04
\end{tabular}

2 Perbandingan elemen sub kriteria level II berdasarkan sasaran-kriteria: pemilihan server side scripting untuk 0,08 sistem informasi sekolah kejuruan kriteria Technologi Related

3 Perbandingan elemen sub kriteria level II berdasarkan sasaran-kriteria: pemilihan server side scripting untuk 0,00 sistem informasi sekolah kejuruan kriteria User Related

4 Perbandingan elemen sub kriteria level II berdasarkan sasaran-kriteria: pemilihan server side scripting untuk sistem informasi sekolah kejuruan kriteria Vendor Related

5 Perbandingan elemen alternatif level III berdasarkan sasaran-kriteria-sub kriteria: pemilihan server side scripting untuk sistem informasi sekolah kejuruan kriteria Technology Related sub kriteria Scalability

6 Perbandingan elemen alternatif level III berdasarkan sasaran-kriteria-sub kriteria: pemilihan server side scripting untuk sistem informasi sekolah kejuruan kriteria Technology Related sub kriteria Availability

7 Perbandingan elemen alternatif level III berdasarkan sasaran-kriteria-sub kriteria: pemilihan server side scripting untuk sistem informasi sekolah kejuruan kriteria Technology Related sub kriteria Features

8 Perbandingan elemen alternatif level III berdasarkan sasaran-kriteria-sub kriteria: pemilihan server side scripting untuk sistem informasi sekolah kejuruan kriteria Technology Related sub kriteria Fleksibility

9 Perbandingan elemen alternatif level III berdasarkan sasaran-kriteria-sub kriteria: pemilihan server side scripting untuk sistem informasi sekolah kejuruan kriteria Technology Related sub kriteria Implementabilit

10 Perbandingan elemen alternatif level III berdasarkan sasaran-kriteria-sub kriteria: pemilihan server side scripting untuk sistem informasi sekolah kejuruan kriteria Technology Related sub kriteria System Requirements

11 Perbandingan elemen alternatif level III berdasarkan sasaran-kriteria-sub kriteria: pemilihan server side scripting untuk sistem informasi sekolah kejuruan kriteria Technology Related sub kriteria Reliability

12 Perbandingan elemen alternatif level III berdasarkan sasaran-kriteria-sub kriteria: pemilihan server side scripting untuk sistem informasi sekolah kejuruan kriteria Technology Related sub kriteria Efficiency

13 Perbandingan elemen alternatif level III berdasarkan sasaran-kriteria-sub kriteria: pemilihan server side scripting untuk sistem informasi sekolah kejuruan kriteria Technology Related sub kriteria Usability

14 Perbandingan elemen alternatif level III berdasarkan sasaran-kriteria-sub kriteria: pemilihan server side scripting untuk sistem informasi sekolah kejuruan kriteria Technology Related sub kriteria Maintainability

15 Perbandingan elemen alternatif level III berdasarkan sasaran-kriteria-sub kriteria: pemilihan server side scripting untuk sistem informasi sekolah kejuruan kriteria Technology Related sub kriteria Security

16 Perbandingan elemen alternatif level III berdasarkan sasaran-kriteria-sub kriteria: pemilihan server side scripting untuk sistem informasi sekolah kejuruan kriteria User Related sub kriteria Customization

17 Perbandingan elemen alternatif level III berdasarkan sasaran-kriteria-sub kriteria: pemilihan server side scripting untuk sistem informasi sekolah kejuruan kriteria User Related sub kriteria User Friendliness

18 Perbandingan elemen alternatif level III berdasarkan sasaran-kriteria-sub kriteria: pemilihan server side scripting untuk sistem informasi sekolah kejuruan kriteria User Related sub kriteria Integration with other application

19 Perbandingan elemen alternatif level III berdasarkan sasaran-kriteria-sub kriteria: pemilihan server side scripting untuk sistem informasi sekolah kejuruan kriteria Vendor Related sub kriteria Support

20 Perbandingan elemen alternatif level III berdasarkan sasaran-kriteria-sub kriteria: pemilihan server side scripting untuk sistem informasi sekolah kejuruan kriteria Vendor Related sub kriteria Maintenance

Dapat disimpulkan bahwa perbandingan berpasangan yang diberikan responden ahli dari keseluruhan memiliki nilai rasio inkonsistensi yang lebih kecil dari 0,1 sebagai batas maksimum nilai rasio inkonsistensi kecuali untuk level 2 kriteria Vendor Related memiliki nilai rasio inkonsistensi 0,11 (marjinal). Namun, dengan demikian hasil perhitungan geometrik gabungan data responden cukup konsisten. Dari hasil pengujian di atas dapat diambil berbagai implikasi penelitian yaitu dilihat dari aspek sistem, aspek manajerial, maupun aspek penelitian lanjutan.

1) Aspek Sistem

Berdasarkan hasil penelitian menunjukkan bahwa Security atau keamanan sistem itu sangat penting sehingga mendapat respon yang tajam dari para responden. Faktor keamanan menjadi penting, karena tujuan 
utama dari sebuah sistem informasi yaitu menjaga data yang ada dari keisengan orang yang mau mengorek data yang dimiliki oleh sebuah sistem informasi. Oleh sebab itu, dalam pemilihan perangkat lunak khususnya untuk aplikasi sistem informasi berbasis web, maka pemilihan server side scripting itu sangat penting dilihat dari sistem keamanan yang di milikinya.

2) Aspek Manajerial

Lebih menitikberatkan pada sisi user. Berdasarkna hasil penelitian ini membuktikan bahwa kriteria User Related menjadi prioritas utama dalam pemilihan server side scripting. Oleh karena itu, disarankan agar dalam pemilihan server side scripting untuk sistem informasi sekolah menggunakan perangkat lunak (server side scripting) yang terkait dengan sisi user, terutama dilihat dari kemudahan penggunaan (user friendliness) yang mendapat point tertinggi dari para responden.

Salah satu keunggulan dari PHP sehingga dipilih oleh para responden ahli yaitu sebagai server side scripting yang memiliki kelompok komunitas pengguna (support) yang cukup banyak terutama untuk sistem informasi yang berbasis web. Bahkan sebagian besar sistem informasi berbasis web lebih banyak menggunakan PHP.

\section{Penelitian Selanjutnya}

Penelitian selanjutnya yang dapat dilakukan yaitu dengan mengekplorelasi sub kriteria user friendliness. Berdasarkan hasil penelitian menunjukkan bahwa masalah faktor kemudahan dalam penggunaan (user friendliness) mendapat perhatian yang sangat penting dari para responden ahli. Selain itu, dapat dikembangkan lagi bagi peneliti selanjutnya dimana hasil penelitian ini dapat diadopsi untuk pemilihan server side scrpting untuk sistem informasi yang lain. Serta ini bisa di implementasikan dalam sebuah program berbasis web, sehingga sistem informasi sekolah dapat menjadi sebuah sistem informasi yang memberikan informasi yang akurat dan juga memiliki keamanan sistem yang baik.

\section{Kesimpulan}

Berdasarkan hasil pembahasan dan analisis, maka tulisan ini mendapatkan kesimpulan bahwa PHP, merupakan server side scripting yang dipilih oleh para responden ahli untuk diterapkan pada sistem informasi sekolah kejuruan Yapimda. PHP memenuhi unsur kriteria dan sub kriteria yang telah ditentukan dalam penelitian ini dengan mendapat bobot tertinggi, karena PHP dinilai memiliki kemanan (security) sistem yang cukup baik, kemudahan dalam penggunaan (user friendliness), dan juga memiliki support yaitu mempunyai komunitas pengguna yang cukup banyak sehingga dipilihlah PHP sebagai server side scripting yang cocok untuk sistem informasi sekolah kejuruan Yapimda. Metode dan evaluasi yang digunakan dalam pemilihan server side scripting untuk sistem informasi sekolah kejuruan Yapimda yaitu dengan teknik pendekatan Analicital Hierarcy Process (AHP, yang dalam penentuan kriteria pemilihan berdasarkan metode penelitian Oyku Alanbay [5].

\section{Referensi}

[1] Anonim, BAB 2 Landasan teori : Server Side Sripting. 2012.

[2] Hartono and Jogiyanto, Analisis dan Desain Sistem Informasi. Yogyakarta, Indonesia: Penerbit Andi, 2005.

[3] Marimin, Teknik dan Aplikasi Pengambilan Keputusan Kriteria Majemuk, 2nd ed. Jakarta, Indonesia: Grasindo, 2005.

[4] V. I. Pareja. (2004) Expert Choice Tutorial. [Online]. http://cashflow88.com/decisiones/saaty2.pdf

[5] O. Alanbay, "ERP Selection Using Expert Choice Software," in International Symposium on the Analytic Hierarchy Process, Honolulu, Hawai, 2005.

[6] H. Magdalena. (2011) Pemilihan Software Berbasis Open Source untuk Aplikasi Digital Library Berbasis Web: Studi Kasus Komparasi GDL, Senayan dan Greenstone. [Online]. http://jurnal.atmaluhur.ac.id/wpcontent/uploads/2012/02/pemilihan-softwareberbasisopensourceuntuk-aplikasi-digitallibrary-berbasis-web.pdf

[7] P. P. Widodo, "Pemilihan Ragam Metode dan Instrumen Penelitian yang Berbasis TIK," in Lokakarya Penelitian dan Pengembangan Bidang TIK, Bogor, 2010.

[8] S. R. Pressman, Rekayasa Perangkat Lunak. Yogyakarta, Indonesia: Penerbit Andi, 2002. 